\title{
$\mathrm{MAC} / \mathrm{PHY}$ 정보를 이용한 실시간 멀티미디어 서비스의 QoS 제어 방식의 표준화를 위한 연구 김 민 건 ${ }^{\mathrm{a})}$, 김 준 오), 서 덕 영 $)^{\ddagger}$
}

\section{Research of QoS Control for Standardization on Real-time Multimedia Service Using MAC/PHY Feedback}

\author{
Min Geon Kim ${ }^{\text {a)}}$, Junoh Kim ${ }^{\text {a)}}$, and Doug Young $\operatorname{Suh}^{\text {a) }}$ \\ 요 약
}

본 논문에서는 모바일 환경에서 클라이언트의 MAC/PHY 파라미터를 이용하여 QoS(Quality of Service)를 제어하는 프로토콜과 그 효과에 대해 연구한다. 클라이언트는 자신의 $\mathrm{MAC} / \mathrm{PHY}$ 채널 상황을 측정하여 서버측에 피드백하고 서버는 이를 이용하여 앞으로의 클라이언트의 상황을 예측하고 비트율 제어를 수행하는 방법을 제안한다. 제안 방법을 통해 기존의 RTCP(Real-time Transport Control Protocol)를 이용한 비트율 제어 방법보다 정확하게 가용 비트율을 예측할 수 있다. 정확한 가용 비트율 예측을 통해 비트율 낭비와 전송지연을 감소시키고, 비디오 전송 시 화질을 향상시킬 수 있다. WiMAX 환경에서 실제로 측정된 클라이언트의 CINR (Carrier to Interface Noise Ratio) 데이터를 활용하여 그 효과를 보여준다.

\begin{abstract}
In this paper, we study QoS(Quality of Service) control protocols and the effect using MAC/PHY parameters of client device in mobile network. We proposes the way of controling the bit-rate by estimating the channel condition of the client with measured MAC/PHY parameters which is sent from the client. With the proposed method, more accurate available bit-rate can be estimated compared to conventional protocol, RTCP(Real-time Transport Control Protocol). The accurate bit-rate estimation can decrease wasted bit-rate and transport delay. In the result of the advantages, the transported video quality can be enhanced. In this paper, we show the effects of enhancement using client's the field data measured in WiMAX.
\end{abstract}

Keyword : Scalable Video Streaming, QoS, Cross Layer Design

a) 경희대학교

Kyung Hee University

‡ 교신저자 : 서덕영 (suh@khu.ac.kr)

※ 본 연구는 지식경제부 및 정보통신산업진흥원의 대학 IT 연구센터 지원 사업의 연구결과로 수행되었음 (NIPA-2011-(C1090-1111-0001))

- 접수일(2011년6월29일), 수정일(1차:2011년8월30일,2차:9월19일),게재확정일 (2011년9월23일)

\section{I. 서 론}

최근 휴대용 단말기들이 널리 사용됨에 따라 무선 네트 워크 환경을 바탕으로 한 비디오 스트리밍 서비스가 이슈 화되고 있다. 비디오 스트림은 $3 \mathrm{G}, \mathrm{WiFi}, \mathrm{WiMAX}^{[1]}$ 등 서 로 다른 특징을 갖는 무선 네트워크 환경에서 전송될 수 
있다. 본 논문에서는 그 중에서 IEEE 802.16 표준에 명시된 WiMAX네트워크 환경에서의 멀티미디어 스트리밍에 초 점을 두고 연구한다. WiMAX는 다른 무선 네트워크 시스 템에 비해 전송 속도가 빠르고 비교적 넓은 범위를 커버할 수 있기 때문에 멀티미디어 스트리밍 서비스에 효율적으로 활용할 수 있다 ${ }^{[2]}$. WiMAX 네트워크에서의 비디오 스트리 밍과 관련하여 $\mathrm{Wang}^{[3]}$ 는 다중 기지국 WiMAX시스템에서 멀티캐스트/브로드캐스트 서비스(multicast/broadcast service)를 위한 시스템 구조와 계층 교차적 최적화(CrossLayer Optimization, CLO)을 제안하였다. Hosein ${ }^{[4]}$ 는 WiMAX 네트워크에서 브로드캐스팅을 위한 가변 비트율 (Variable Bit Rate, VBR 스트림 스케쥴링 방법을 제안하였 고, $\mathrm{Juan}^{[5]}$ 은 WiMAX 네트워크에서 계층적 비디오 스트림 을 전송하기 위한 방법을 제안하였다.

이처럼 WiMAX 환경에서 효율적인 비디오 스트리밍 을 위한 방법들에 대한 선행 연구가 많이 진행되었는데
WiMAX와 같은 무선 네트워크의 가장 큰 특징은 수신 신호 세기가 불규칙하게 변화한다는 것이다. 수신 신호 세기가 변 화한다는 것은 가용 비트율이 변화한다는 것을 의미하고 이 는 비디오 스트리밍 시 손실 및 화질 저하를 가져올 뿐만 아니 라 자원을 효율적으로 사용하지 못하는 상황이 발생할 수도 있다. 이를 해결하기 위해 네트워크 상황에 맞게 비디오 스트 리밍 자원을 할당하는 방법에 관한 방법이 제안되었다 ${ }^{[6[7]}$. 서버에서 비디오의 비트율을 조절하여 전송하는 비트율 제어 대한 선행 연구가 진행되어 왔는데 특히 실시간 전송 제어 프로토콜 (Real-time Transport Control Protocol, RTCP)를 이용하여 비트율 제어를 수행하는 방법이 있다. $\mathrm{RTCP}$ 는 응용 계층에서 비트율 제어 등을 목적으로 클라이 언트의 통신 상황을 보고하는 패킷을 주고 받는 것에 대한 프로토콜이다. $\mathrm{Kim}^{[8][9]}$ 은 RTCP를 사용하여 서버가 클라이 언트의 네트워크 상황을 피드백 받은 후 비디오의 비트율 제어를 수행하는 방법을 제안하였다.

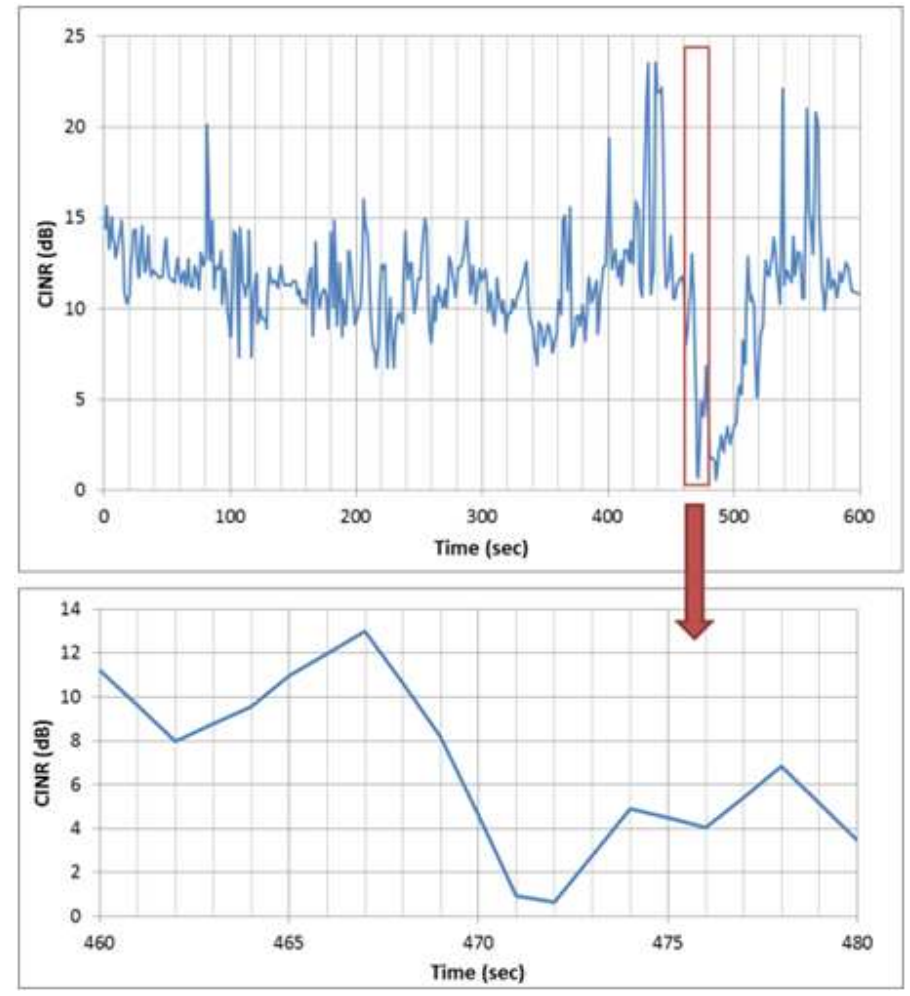

그림 1. WiMAX 환경에서 실제 측정한 CINR 데이터

Fig. 1. The field data measured in WiMAX 
RTCP는 end-to-end 프로토콜이므로 전체 경로에 대한 피드백 방식을 제공하지만, 제공된 정보는 하부 계층에서 제공하는 정보에 비하여 늦고 부정확하다. 피드백이 늦게 되면 피드백을 하는 사이에 네트워크 상황이 바뀔 수 있으 므로 비트율 제어가 부정확하게 된다. 특히 무선망에서는 채널의 환경이 매우 빠르게 바뀐다. 이를 해결하기 위해 본 논문에서는 하위 계층의 정보 교환을 통해 적응적으로 피 드백 주기 및 방법을 조절하고 미래값을 예측하여 빠른 비 트율 제어를 수행할 수 있도록 한다. 제안 방법과 RTCP를 통한 비트율 제어와의 가용 비트율 예측의 정확도를 비교 하고 비디오 스트리밍 시 미치는 영향에 대해 분석한다.

본 논문에서는 클라이언트가 주기적 혹은 급격한 채널상 황 변화 시 서버에게 채널 상황을 피드백하고 서버는 이를 비트율 제어에 적용하는 방법을 제안한다. 이때 피드백 주 기와 방법을 어떻게 결정할 것인지, 비트율 제어에서 가중 치와 채널 버퍼 사이즈를 어떻게 결정한 것인지에 대해 연 구한다. 본 논문에서는 독일 하노버의 북쪽 방향 로텐버그 (Rotenburg) 지역에서 실제로 이동하면서 위도와 경도, $\mathrm{CINR}$, 시간 등을 기록한 data를 활용한다. 그림 1 은 측정한 $\mathrm{CINR}$ 의 일부를 나타낸다. 그림 1 에서 보듯이 채널 상황은 매우 빠르게 바뀌고 있으며 RTCP로 이를 추적해나가기는 매우 어렵다.

본 논문의 구성은 다음과 같다. 2장에서 피드백을 위한 $\mathrm{MAC} / \mathrm{PHY}$ 정보 추상화에 대해 설명하고 3장에서는 신호 세기 피드백을 이용한 비트율 제어 방법을 제안한다. 4장에
서 실험 결과를 분석하고 끝으로 5장에서 결론을 맺는다.

\section{II. 피드백을 위한 $\mathrm{MAC/PHY} \mathrm{정보} \mathrm{추상화}$}

현재 RTCP를 이용한 네트워크 상태정보를 활용하는 것 이 일반적이다. 그러나 RTCP는 $\mathrm{MAC} / \mathrm{PHY}$ 등 하부 계층의 상태에 의해 일어난 결과를 측정하는 것이므로 피드백 시 지연이 크고 측정된 값도 네트워크의 상태를 나타내기에는 부정확하다. 이러한 이유로 $\mathrm{MAC} / \mathrm{PHY}$ 파라미터를 직접 이 용하는 것이 현재 사용되고 있는 RTCP를 이용한 네트워크 상태 정보를 획득하는 것보다 효과적이다.

하지만 서로 다른 $\mathrm{MAC} / \mathrm{PHY}$ 프로토콜은 각각 그것들만 의 다른 $\mathrm{MAC} / \mathrm{PHY}$ 파라미터를 갖고 있기 때문에 응용 계 층에서 각각 다른 프로토콜의 파라미터들을 사용하는데 어 려움이 있다. 그러나 각기 다른 프로토콜의 $\mathrm{MAC} / \mathrm{PHY}$ 파 라미터들은 유사한 정보들을 갖고 있다. 예를 들면, 신호 대 잡음비는 $\operatorname{SINR(Signal~to~Interference~Ratio),~CINR~}$ (Carrier to Interference Ratio), SIR(Signal to Interference Ratio)등으로 유사하게 표현된다. IEEE802.16 (WiBRO 또 는 WiMAX), IEEE802.11 (WiFi), 3GPP W-CDMA, 3GPP $\mathrm{LTE}$ 등 모든 모바일 망이 $\mathrm{MAC} / \mathrm{PHY}$ 정보를 제공하지만 통일되어 있지 않으므로 응용계층에서 이용하기 어렵다. MPEG MMT에서 이 정보들을 추상화하여 제공하면, 기존의 모바일 표준은 물론이고 미래의 모바일 표준에서 이 추상화

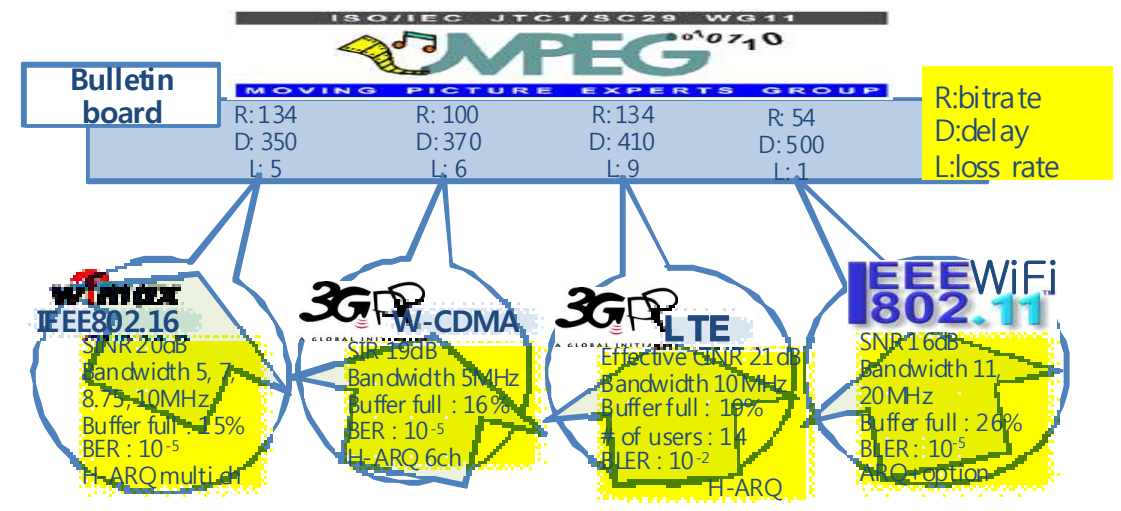

그림 2. 적응적 QoS 제어를 위한 네트워크 추상화의 개념

Fig. 2. Concept of network abstraction for QoS control 
된 정보를 제공함으로써 응용계층에서 활용할 수 있게 된다.

이와 관련하여 MPEG(Moving Picture Experts Group)의 system 세션에서 표준화를 진행중인 MMT(MPEG Media Transport)에서 본 논문과 관련있는 $\mathrm{CLD}$ (Cross Layer Design)파트에NAM(Network Abstraction for Media)이라 는 명칭으로 서로 다른 프로토콜의 $\mathrm{MAC} / \mathrm{PHY}$ 계층의 유사 한 파라미터를 통합하는 네트워크 추상화 계층 정보를 제 안하였다. 그림 2 는 제안된 네트워크 추상화 계층 정보의 개념을 나타낸다. 추상화하여 표현하는 정보는 이미 대부 분의 망에서 사용하고 있는 RSVP의 tSpec과 RTCP에서 사 용하는 $\mathrm{QoE}$ 인자의 형태가 적합하다.

이렇게 추상화된 정보는 MPEG DASH(Dynamic Adaptive Streaming over HTTP)와 같이 클라이언트 기반 방식에 서는 클라이언트에서 바로 사용할 수 있다. RTCP와 같이 서 버 기반 방식에서는 서버가 $\mathrm{QoS}$ 제어를 하기 위해 클라이언 트로부터 네트워크 추상화 계층 정보가 피드백되어 전달되 어야 한다. 일반적으로 $\mathrm{MAC}$ 계층과 $\mathrm{PHY}$ 계층의 채널 파라 미터들은 매우 빠르게 $(10 \mathrm{~ms})$ 변화한다. 따라서 시간 변화에 따른 채널 상태가 즉시 반영될수록 유용하게 사용할 수 있다. 채널 상황이 변화하거나 사용자가 채널 상황을 읽어 들이는
것에 따라 주기적 혹은 비주기적으로 피드백될 수 있다. 응용 계층이 NAM bulletin board로부터 정보를 읽는 것과 독립적 으로 $\mathrm{MAC} / \mathrm{PHY}$ 계층은 NAM bulletin board의 정보를 업데 이트한다. 그림 3은 NAM 피드백 흐름도를 나타낸다.

$\mathrm{NAM}$ 정보의 정의와 의미는 다음과 같다. 표 1 은 NAM 파라미터들을 나타낸다. 많은 정보들이 $\mathrm{MAC} / \mathrm{PHY}$ 계층에 서 제공되지만 응용 계층에서는 그것들이 모두 필요하지는 않다. 응용 계층의 $\mathrm{QoS}$ 제어를 위해 비트율, 지연, 손실율 등과 같은 몇몇의 파라미터들이 멀티미디어 전송시 매우 중요하다. RSVP(ReSourcereser Vation Protocol) 필드에

표 1. 네트워크 추상화 계층 정보 (NAM 정보)

Table 1. Network Abstraction for Media (NAM Information)

\begin{tabular}{|c|c|c|}
\hline Field & Type & size (bits) \\
\hline channel_id & unsigned integer & 6 \\
\hline token_bucket_rate & Float & 32 \\
\hline token_bucket_size & Float & 32 \\
\hline peak_data_rate & Float & 32 \\
\hline maximum_delay & Float & 32 \\
\hline frame_size & unsigned integer & 32 \\
\hline $\begin{array}{c}\text { frame_loss_ratio / } \\
\text { lost_frame_number }\end{array}$ & float / unsigned integer & 32 \\
\hline
\end{tabular}

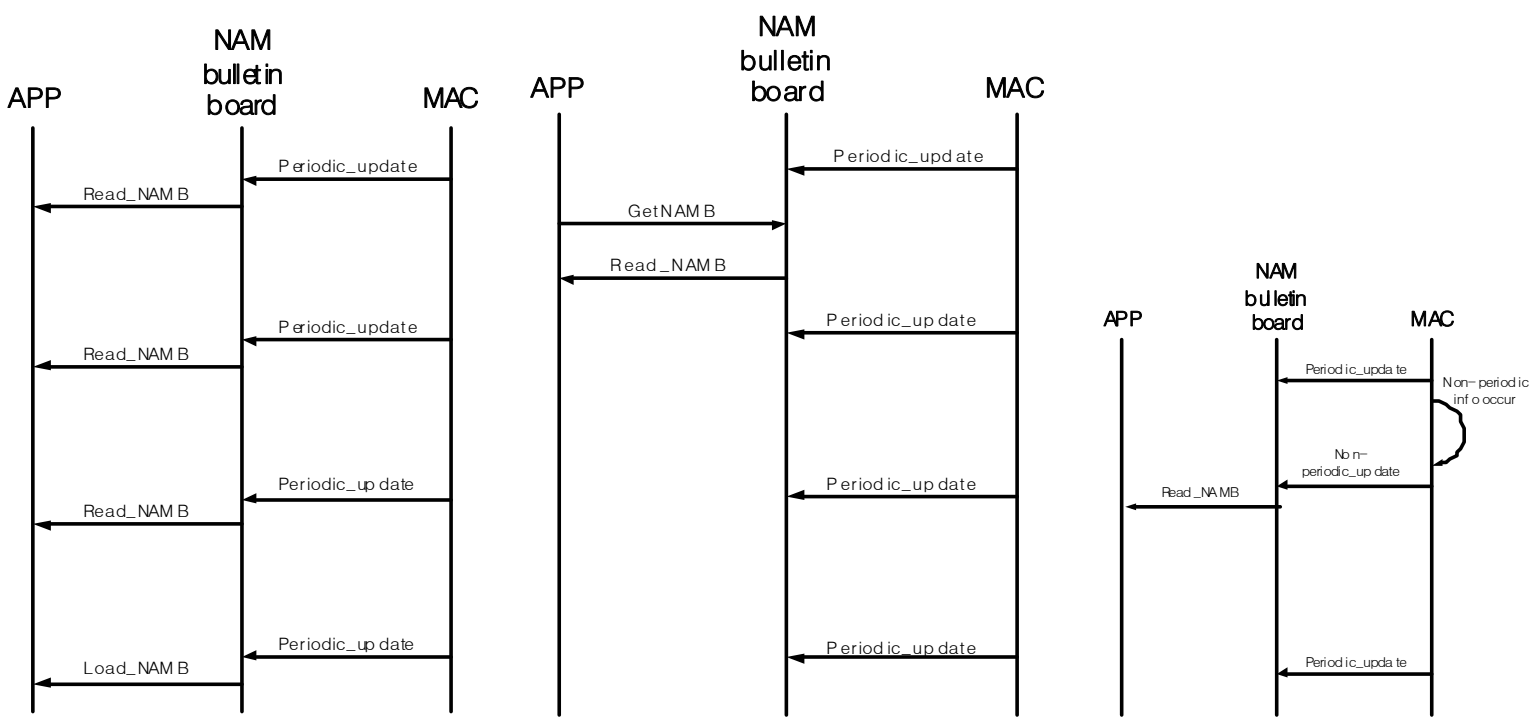

그림 3. MAC 계층과 응용(APP) 계층에서 NAM을 이용하여 정보를 교환하는 흐름도 a)일반적으로 NAM 정보가 사용되는 경우 b)사용자의 요구에 의한 NAM 정보가 사용되는 경우 c)비주기적으로 NAM 정보가 load되는 경우

Fig. 3. Flowchart of exchange information using NAM 
응용 계층의 $\mathrm{QoS}$ 제어에 적합한 $\mathrm{tSpec}$ 파라미터가 정의되 어 있다. 그리고 지연과 손실율과 같이 $\mathrm{tSpec}$ 에 포함되지 않은 정보들은 $\mathrm{RTCP}$ 에 정의되어 있다. $\mathrm{tSpec}$ 과 $\mathrm{RTCP}$ 는 네트워크 환경에서 널리 쓰이기 때문에 MAC/PHY 파라미 터를 추상화하는데 적합하다. 이런 이유로 tSpec과 RTCP 의 다양한 채널 파라미터들을 추상화하기 위한 정의와 의 미를 제안하였다.

- channel_id: the identifier to classify each network or session

- token_bucket_rate:guaranteed average bit-rate in MAC/PHY layer represented as kilobits per second (kbps).

- token_bucket_size: token bucket depth of the buffer in MAC/PHY layer represented as kilobits (kbits)

- peak_data_rate: available peak bandwidth in MAC/ PHY layer

- maximum_delay: maximum transport delay represented as milliseconds (ms)

- frame_size: size of frame which is the transport unit in MAC/PHY represented as kilobits (kbits)

- frame_loss_ratio/ lost_frame_number: frame loss rate or the numbers of frame loss calculated in MAC/PHY layer

\section{III. 신호세기 피드백을 이용한 비트율 제어 방법}

그림 4는 본 논문에서 제안하는 피드백 시스템의 기본 구조이다. 클라이언트가 자신의 채널 상황을 피드백하고 피드백 받은 값에 따라 서버는 비트율 제어를 하게 된다. 이때 서버의 전송 비트율과 클라이언트의 수신 가능 비트 율이 다를 경우 차이를 저장하기 위해 기지국(Base station)에 채널 버퍼(channel buffer)를 설정한다. 이번 장에 서는 1)클라이언트, 2)클라이언트와 기지국, 3)서버와 기 지국으로 나누어서 각 부분에서 수행하는 과정을 설명하 도록 한다.

\section{1. 클라이언트 (client)}

클라이언트에서는 매 순간 $\mathrm{CINR}$ 값으로 변조 및 코딩 방식 (modulation and coding scheme, MCS)에 따른 수신 가능 비트율 $\mathrm{R}[\mathrm{n}]$ 이 결정된다 ${ }^{[8]}$. 이 방법은 $\mathrm{CINR}$ 의 범위에 따라 사용하는 변조방식과 코딩율 등의 파라미터를 결정하 고 이를 근거로 수신 가능 비트율을 구했다. 본 논문에서는 ${ }^{\left[{ }^{[8}\right.}$ 에서 제안된 $R[n]$ 결정방법을 채택하여 미래의 비트율 $\hat{R}[n]$ 을 예측한다.

자기 상관을 계산하여 현재의 데이터가 이전의 데이터에 얼마나 영향을 받는가를 알 수 있다. 사용한 자기 상관 계수

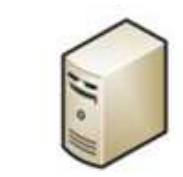

Video server

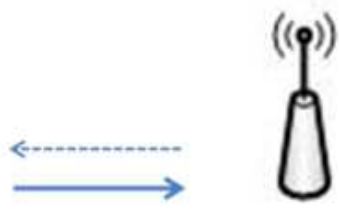

Base station

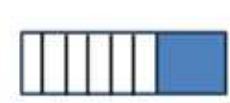

channel buffer

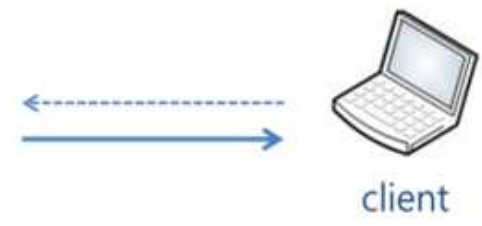

client

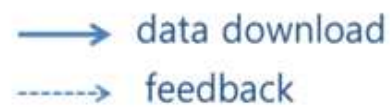

그림 4. 제안하는 시스템 구조

Fig. 4. Concept of proposal system 


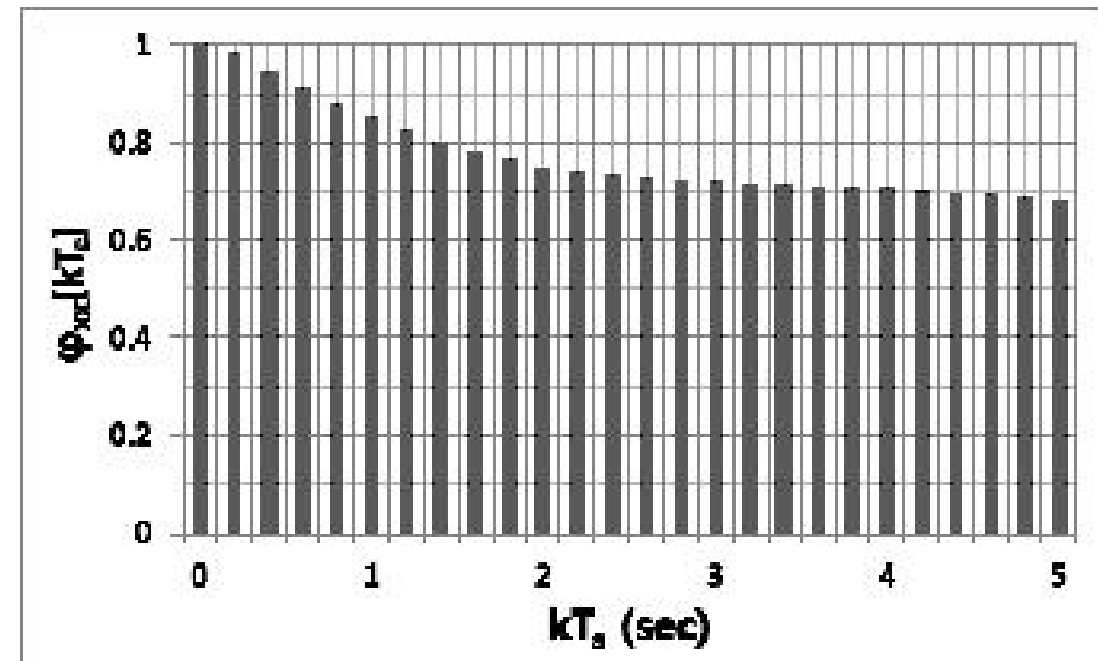

그림 5. CINR X[n]의 자기 상관 (샘플링 주기T_s $=200 \mathrm{~ms}$ )

Fig. 5. Autocorrelation of CINR X[n] (sampling period T_s $=200 \mathrm{~ms}$ )

는 (1)과 같고 그 결과는 그림 5 와 같다. 그림 5 에서는 약 2 시간에 걸쳐 측정한 $\mathrm{CINR}$ 데이터를 $200 \mathrm{~ms}$ 간격으로 나 누어 데이터셋을 구성하여 근접 값과의 상관성을 나타내 었다.

$$
\begin{gathered}
\varphi_{X X}[k]=\frac{E\left[\left(x[n]-\mu_{x}\right)\left(x[n-k]-\mu_{x}\right)\right]}{E\left[\left(x[n]-\mu_{x}\right)^{2}\right]} \\
\text { where } \mu_{x}=E[x[n]]
\end{gathered}
$$

그림 5 를 통해 데이터가 근접할수록 영향이 큼을 알 수 있다. 위의 자료를 통해 $\hat{R}[n]$ 을 예측할 때 이전 데이터의 활용방안과 feedback period T의 결정에 대해 생각해 볼 수 있다. 본 논문에서는 (2)와 같이 연관성이 가장 높은 바로 이전 값을 그대로 사용하도록 한다.

$$
\hat{R}[m K]=R[m K-1] \text { where } \mathrm{K}=\mathrm{T} / \mathrm{T}_{\mathrm{s}}
$$

수식 (2)에서 R은 MCS 단계에 의해 결정된 과거의 비트 율, $\hat{R}$ 는 예측한 앞으로의 비트율이다. $\mathrm{T}$ 는 피드백 주기이 고 $\mathrm{T}_{\mathrm{s}}$ 는 실험 데이터의 샘플링 주기를 의미하는데 본 논문 의 실험에서는 $200 \mathrm{~ms}$ 이다. 클라이언트에서 서버까지의 피 드백 지연은 $200 \mathrm{~ms}$ 라고 가정한다. $\mathrm{m}$ 은 1 이상의 정수이며
예측이 일정한 피드백 주기로 반복되는 것을 나타내기 위 한 값이다.

\section{2. 클라이언트와 기지국 (client and base station)}

Client는 server에게 자신의 채널 상황(CINR)을 피드백 한다. 피드백 방법은 다음과 같이 두 가지로 나누어 수행 한다.

- Fixed Feedback Period(FFP): 일정한 주기(T)로 피드 백 수행

- Feedback at Abrupt Change(FAC): $|R[n]-R[n-1]|$ $>D$ 일 때 피드백 수행

FFP 방법은 피드백 주기를 일정하게 고정적으로 설정하 는 방법이고, $\mathrm{FAC}$ 방법은 현재 값과 이전 값과의 차이가 일정 값(D) 이상일 때 피드백하는 방법이다. $\mathrm{D}$ 를 결정하는 근거는 그림 6 를 이용하도록 한다. 그림 6 의 데이터는 약 2시간에 걸쳐 측정된 CINR 데이터를 가용 비트율(R)로 변 환한 것을 사용하였으며 이전 값과의 비트율 차이 $(R[n]-$ $R[n-1])$ 의 확률분포를 나타낸다. 예를 들어 이전 값과의 차 이가 $200 \mathrm{kbps}$ 이하인 경우는 약 $80 \%$ 이다. 피드백 방법에 


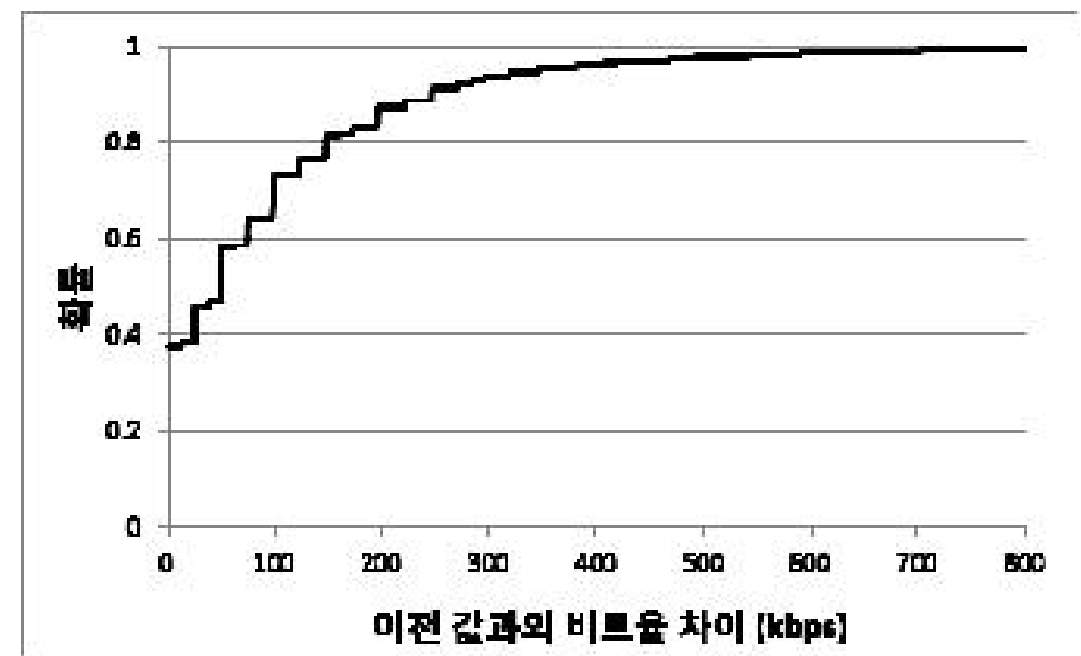

그림 6. 비트율 변화의 현재 값과 이전 값과의 차이에 대한 확률분포

Fig. 6. PDF of difference of $R[n]$ and $R[n-1]$

따라 클라이언트의 수신 가능 비트율과 서버가 전송하는 비트율과의 차이가 달라지게 된다. 이는 3장 실험 결과를 통해 자세히 알아보도록 한다.

\section{3. 서버와 기지국 (server and base station)}

서버에서는 피드백 받은 데이터를 사용하여 전송 비트율 $\mathrm{R}$ ' $\mathrm{n}]$ 을 결정하도록 한다. 서버는 피드백 받은 데이터에 축 소치 (a, scale-down factor)를 곱하여 전송 비트율 R' $[n]$ 을 결정하여 데이터를 전송한다(3). 이 때 기지국에 채널 버퍼 를 두어 R'[n]가 R[n]보다 클 경우 그 차이를 버퍼에 저장하 도록 한다. 채널버퍼 $\mathrm{B}[\mathrm{n}]$ 은 (4)와 같다.

$$
\mathrm{R}^{\prime}[\mathrm{n}]=\hat{R}[n] \times \alpha
$$

$$
\begin{aligned}
B[n] & =\left\{\begin{array}{cc}
0, & \text { if } B[n-1]+R^{\prime}[n]<R[n] \\
B[n-1]+R^{\prime}[n]-R[n] & \text { otherwise }
\end{array}\right. \\
B[0] & =0
\end{aligned}
$$

만약 채널 버퍼 사이즈 $B_{\max }$ 가 제한되어 있다면 채널 버퍼에서 오버플로우가 발생하여 데이터가 손실될 수 있 다. 이를 고려하여 R'[n]을 조절하기 위해 (3)에서 $a$ 가 조
절되어야 한다. 또한 버퍼에 들어온 데이터가 나가는데 까 지 걸리는 시간인 지연이 고려되어야 한다. 지연 식은 (5) 과 같다.

$$
\text { delay }=E\left[\frac{B[n]}{R[n]}\right]
$$

버퍼 오버플로우와 지연을 고려하여 $B_{\max }$ 에 따라 $\alpha$ 가 다르게 설정되어야 한다. 그림 7는 $B_{\max }$ 와 $\alpha$ 에 따른 오버 플로우와 지연의 관계를 나타낸다. 스트리밍 서비스의 경 우엔 비교적 지연을 허용하고 대화형 서비스의 경우 지연 에 매우 민감하기 때문에 두 경우로 나누어 실험하였다. 그 림 7에서 $B_{\max }$ 의 크기와 $\alpha$ 에 따라 오버플로우가 발생하는 경우를 나타낼 수 있다. $B_{\max }$ 가 작거나 $\alpha$ 가 큰 값일 때 오 버플로우가 발생하는 것을 알 수 있다. 그림에서 점선은 오 버플로우가 발생하는 경우와 발생하지 않는 경우를 구분하 는 선이다. 즉 점선을 따라 오버플로우가 발생하지 않는 최 소의 $B_{\max }$ 와 최대의 $\alpha$ 을 구할 수 있다. 또한 각 경우의 지 연을 계산하여 스트리밍 서비스의 경우 약 2 3초의 지연을 허용하는 접점을 구하였고, 대화형 서비스의 경우 약 $300 \mathrm{~ms}$ 의 지연을 허용하는 접점을 구하였다. 그 결과 스트 리밍 서비스의 경우 $\alpha=0.99, B_{\max }=20 \mathrm{Mbits}$ 이며, 대화형 


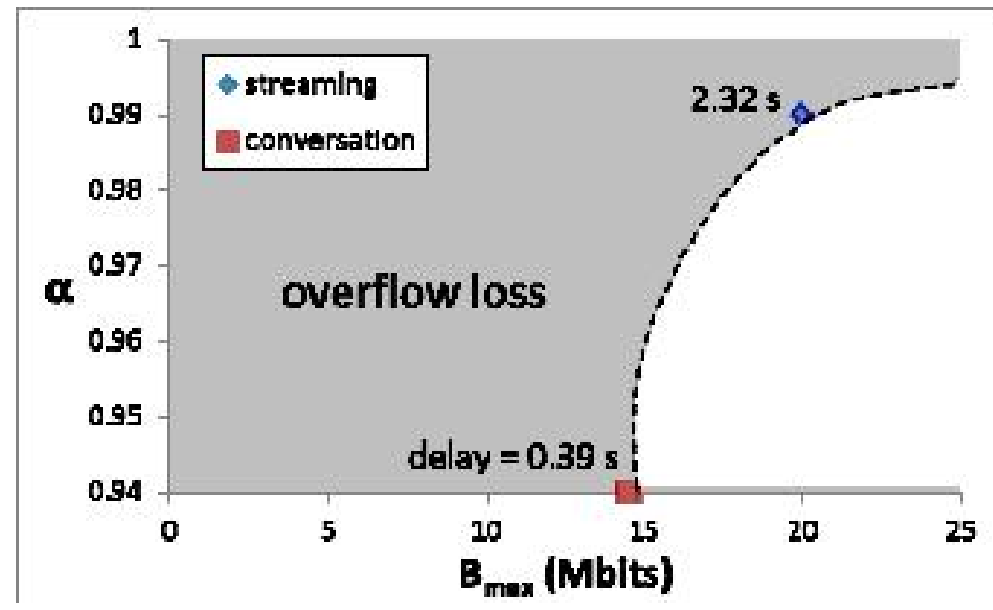

그림 7. B_max와 a에 따른 오버플로우와 지연

Fig. 7. Overflow and delay according to $B_{-} \max$ and $a$

서비스의 경우 $\mathrm{a}=0.94, \mathrm{~B} \max =14.5 \mathrm{Mbits}$ 이다. 본 논문의 실험에서는 이 값으로 진행하도록 한다.

본 논문의 제안 방법과 비교하기 위한 기존 방법으로 RTCP의 Round Trip Time (RTT)를 이용한 비트율 제어 방 법을 사용하였다. RTCP에서 RTT는 서버와 클라이언트 간 의 데이터를 주고 받는 지연을 의미하기 때문에 본 논문의 실험에서는 채널 버퍼의 지연을 측정하여 비트율을 제어하 는 것을 비교 대상으로 설정한다. 버퍼 지연을 이용한 비트 율 제어방법은 서버가 버퍼 지연을 피드백 받고 지연이 일 정 시간 이상일 경우에는 전송 비트율을 낮추고, 일정 시간
이하일 경우에는 전송 비트율을 높이는 방법을 사용한다. 이때 일정 시간은 그림 7 를 근거로 하여 스트리밍 서비스의 경우 2.32 초로 하고, 대화형 서비스의 경우 0.39 초로 한다.

\section{IV. 실험 결과 및 분석}

장의 실험은 실제 측정한 CINR 데이터를 기반으로 모 의 실험을 하였으며 비디오 테스트 시 인코딩은 $\mathrm{SVC}$ 로 하 였으며 실험 영상은 Soccer $4 \mathrm{CIF}$ 로 SNR 계층을 7계층으로

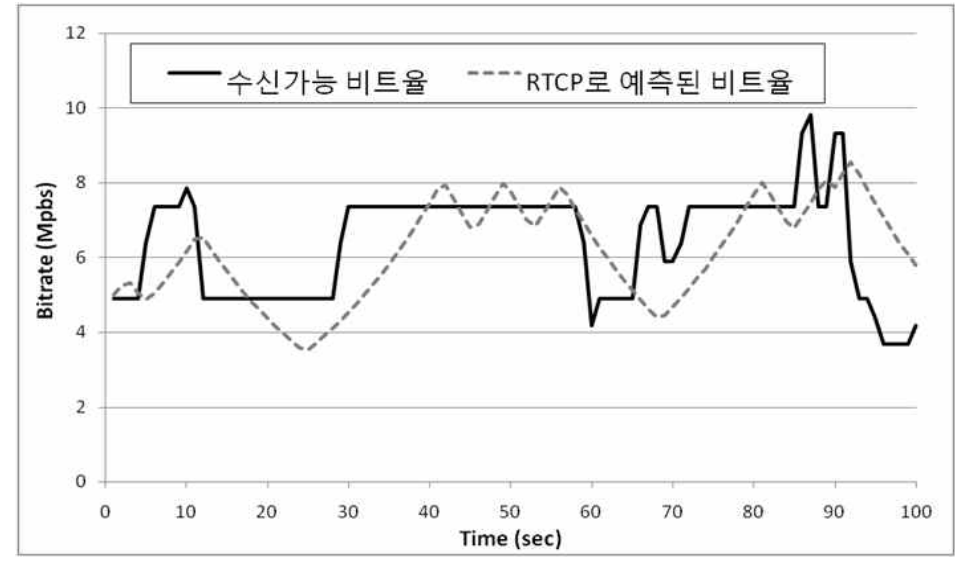

그림 8. RTCP를 통한 비트율 예측

Fig. 8. Prediction of Bit rate using RTCP 


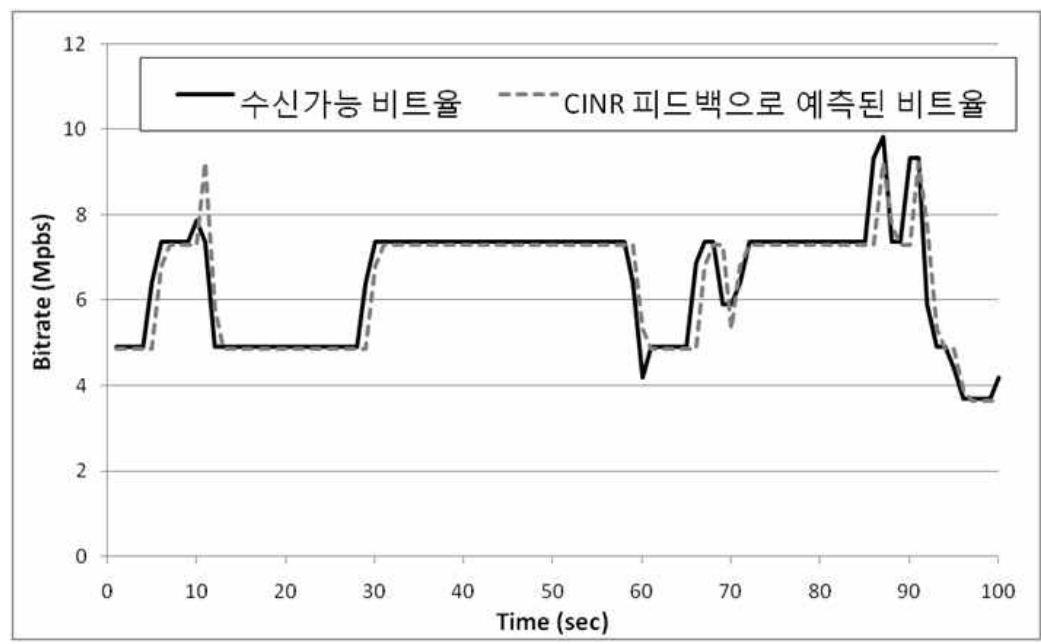

그림 9. CINR 피드백을 이용한 비트율 예측

Fig. 9. Prediction of Bit rate using CINR feedback

나누어 비트율 제어를 수행한다. 그림 8은 RTCP를 이용한 비트율 제어 방법으로 버퍼 지연을 이용하여 비트율을 예 측한 경우를 나타낸다. 그림 8,9 에서 수신가능 비트율은 본3.1절에서 소개한 $\mathrm{CINR}$ 값과 변조 및 코딩 방식 (MCS)에 따른 사용 가능 비트율을 의미한다. 버퍼의 지연 을 이용하여 비트율을 예측하고 제어했기 때문에 다소 비 트율 적용이 늦어지는 것을 알 수 있다. 이를 보완하기 위한 방법으로 본 논문에서는 CINR 피드백을 이용한 비트율 제
어 방법을 제안하였으며 제안 방법을 통해 비트율을 예측 한 결과는 그림 9 와 같다. 그림 9 에서 피드백 방법은 FFP 방법의 $\mathrm{T}$ 가 1 초인 경우이다. 1 초 간격이기 때문에 더 세세 한 부분에서는 오차가 발생하지만 Fig.8의 기존 방법과 비 교하였을 때 예측이 훨씬 정확함을 알 수 있다. 이는 즉 더 빠른 예측이 됨을 의미한다.

그림 10 은 실제 수신가능 비트율과 예측 비트율의 차이 를 평균으로 계산하여 하나의 그래프로 나타낸 것이다. 그

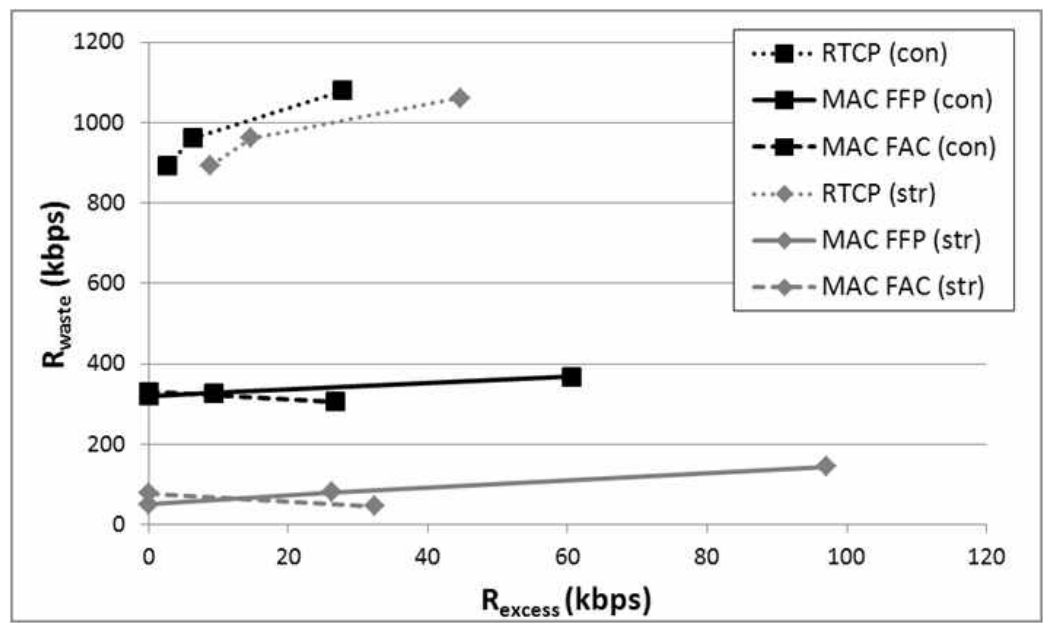

그림 10. CINR 피드백을 이용한 비트율 제어 방법과 RTCP를 통한 제어 방법의 성능 비교 (con과 str은 각각 대화형 서비스와 스트리밍 서비스를 의미한다.) Fig. 10. A comparison of the method using CINR feedback and RTCP (con:conversation, str:streaming) 
림 10 에서 세로축의 Rwaste는 예측한 대역폭이 주어진 가 용 대역폭보다 작을 경우 차이인 낭비되는 대역폭을 의미 한다. 가로축의 Rexcess는 예측한 대역폭이 주어진 가용 대 역폭보다 클 경우 차이인 초과된 대역폭을 의미한다. 여기 서 낭비 및 초과는 제한적으로 설정한 버퍼를 고려한 것이 다. 즉 중간에 버퍼가 존재하고 서버는 버퍼에게 예측한 비 트율만을 전송하고, 클라이언트는 가용 비트율만큼 버퍼로 부터 데이터를 받는다. 이때 버퍼가 언더플로우 혹은 오버 플로우가 발생할 때 클라이언트 측에서는 대역폭의 낭비나 초과가 발생하는 것이다. 그림에서 좌측 하단으로 갈수록 대역폭의 낭비나 초과가 적고 비트율 제어가 정확히 이루 어졌다고 할 수 있다.

실험은 스트리밍 서비스(str)의 경우와 대화형 서비스 (con)의 경우로 나누어서 실험하였으며 본 논문에서 제안 한 두 가지 피드백 방법인 FFP와 FAC, 그리고 비교 방법인 $\mathrm{RTCP}$ 를 통한 경우로 나타내었다. 세 가지 경우의 실험 데 이터는 FFP 방법의 경우 $\mathrm{T}$ 를 $1,3,5$ 초로 설정하고, $\mathrm{FAC}$ 방 법의 경우 $\mathrm{D}$ 를 $200,300 \mathrm{kbps}$ 로 설정하여 출력하였다. FFP 방법은 $\mathrm{T}$ 가 클수록 예측이 부정확하며, $\mathrm{FAC}$ 방법은 $\mathrm{D}$ 가 클수록 피드백이 덜 이루어지므로 부정확한 비트율 예측이 수행된다.
대화형 서비스의 경우 같은 방법으로 수행한 스트리밍 서비스와 비교하여 낭비되는 데이터가 많고 초과되는 데이 터가 적은 이유는 지연을 더 적게 하기 위하여 2.3절에서 전송 비트율을 결정할 때 가중치를 작게 설정하였기 때문 이다. 즉 지연에 민감한 대화형 서비스에서는 비교적 적은 비트율로 전송하여 지연을 줄이는 대신 비트율을 낭비하는 양이 비교적 많이 나타나는 것이다.

실험을 통해 제안방법인 신호세기 피드백을 통한 비트율 제어 방법이 기존의 RTCP를 이용한 비트율 제어 방법보다 낭비되는 비트율을 줄일 수 있음을 나타내었다. 스트리밍 서비스의 경우 약 $800 \mathrm{kbps}$ 만큼 낭비되는 비트율을 줄였으 며 대화형 서비스의 경우 약 $600 \mathrm{kbps}$ 만큼 낭비되는 비트 율을 줄였다. 초과로 인한 데이터 손실은 큰 이득을 얻진 못했지만 낭비되는 비트율을 크게 줄였다는 점에서 성능 향상을 얻을 수 있다.

정확한 가용 비트율 예측을 통해 낭비되는 비트율을 크 게 줄였을 때 비디오 성능에는 어떤 영향을 미치는지에 대 해 실험 결과를 통해 분석하도록 한다. 그림 11 는 제안 방 법과 기존 방법을 통해 비디오 데이터 전송을 적용하였을 때의 PSNR을 비교한 것이다. 제안 방법의 경우 FFP 방법 으로 피드백 주기를 1 초로 설정하였을 경우를 대표로 나타

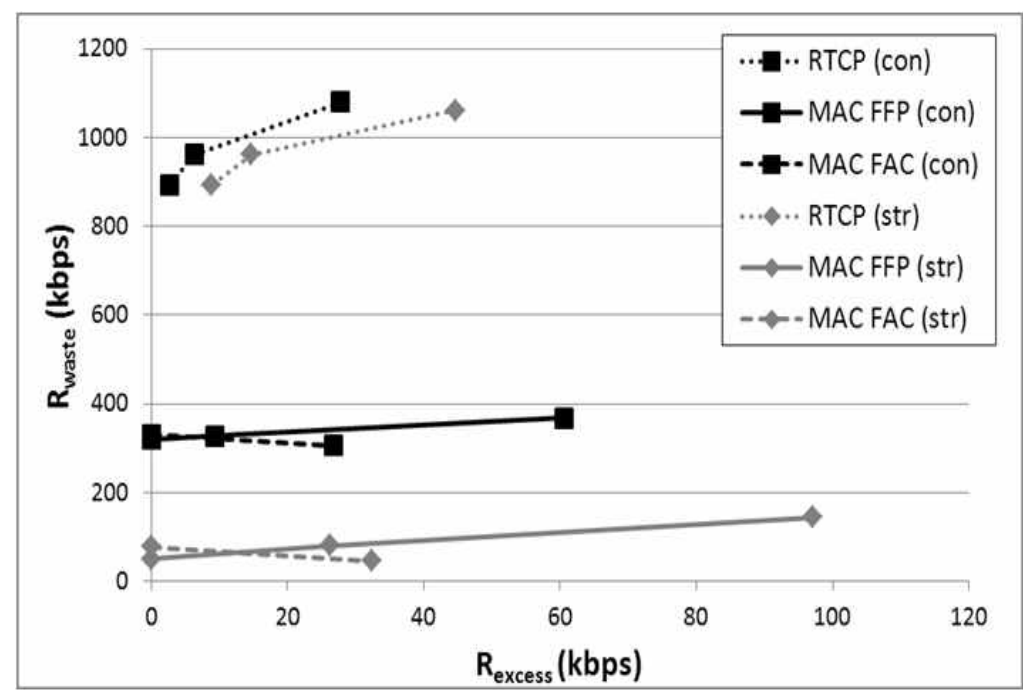

그림 11. 기존 방법과 제안 방법의 비디오 화질 비교 (스트리밍 서비스의 경우)

Fig. 11. A comparison of video quality 
내었다. 기존 방법 또한 공평한 조건을 위해 피드백 주기를 1 초로 설정하였다. 하지만 기존 방법의 경우 같은 주기로 피드백을 하지만 가용 비트율을 정확하게 예측하지 못하여 비트율 제어 수행이 늦어질 수 있다. 제안 방법은 기존 방법 보다 가용 비트율을 정확하게 예측하여 비트율 제어를 하 므로 낭비되는 비트율을 줄여 사용할 수 있는 비트율을 최 대한 사용하여 비디오 화질을 향상시킬 수 있다. 그림 11에 서 5 초 구간에서 기존 방법의 경우 대역폭을 잘못 예측하여 PSNR이 현저하게 떨어지지만 제안 방법의 경우 가용 비트 율을 정확히 예측하여 화질 향상을 보인다.

\section{V. 결 론}

본 논문에서는 실시간 멀티미디어 서비스 향상을 위한 기존의 RTCP 기반 피드백 $\mathrm{QoS}$ 제어 방식의 대안으로 $\mathrm{MAC} / \mathrm{PHY}$ 기반 피드백 $\mathrm{QoS}$ 제어방식을 제시하였다. RTCP 방식은 표준화가 이루어졌고 많이 활용되고 있으나, $\mathrm{MAC} / \mathrm{PHY}$ 방식을 이용한 CLO접근 방법은 빠르고 정확함 에도 불구하고 표준화가 되지 못 하였다. 왜냐하면, 각 인터 넷 계층간의 상호 이해관계가 부족한 면이 있었고, CLO접 근 법을 도용하기 위한 시도 자체가 이루어 지지 않았었다. 이번 MPEG 표준화에서의 CLO접근 방법의 도입은 각기 다른 인터넷 계층 표준화 기구에서 시도되지 않았던 일을 선도 함으로서 각 표준화 기구의 참여를 유도할 수 있는 좋은 기회가 될 것이다. 본 논문에서는 CLO접근 방법의 하 나로, 유사한 $\mathrm{QoS}$ 정보들을 제공하는 각각의 $\mathrm{MAC} / \mathrm{PHY}$ 의 프로토콜들을 추상화하여 통일화하는 방법을 제시하였다.

무선 네트워크 시스템은 수신 신호 세기가 불규칙하게 변화하기 때문에 보다 정확한 대역폭 예측과 비트율 제어 가 필요하다. 기존 방법인 RTCP를 이용한 비트율 제어 방 법은 지연이 발생하여 뒤늦게 대역폭을 예측하고 정확도가 떨어질 수 있다. 이와 비교하여 제안 방법은 대역폭을 예측 하는데 중요한 요소가 되는 PHY계층의 CINR 파라미터를 직접 피드백하고 대역폭 예측 및 비트율 제어가 이루어지 도록 한다.

WiMAX 환경에서 PHY 계층 파라미터인 CINR을 분석
하고 CINR 피드백을 통한 비트율 제어 방법에 대해 연구하 였다. 실제 WiMAX 환경에서 측정된 CINR 데이터의 변화 를 분석하고 미래의 값을 어떻게 예측할 것인가에 대해 제 안하였다. CINR의 변화는 가용 대역폭의 변화를 야기하고 비디오 서비스 시 데이터 손실 및 화질 저하가 발생할 수 있기 때문에 $\mathrm{CINR}$ 의 분석은 매우 중요하다고 할 수 있다. 제안 방법을 통해 기존 방법보다 대역폭의 낭비를 약 600 800kbps 감소시켰으며 이를 통해 비디오 화질이 최대 $5 \mathrm{~dB}$ 정도 향상될 수 있다.

무선 네트워크를 통한 스트리밍 시스템의 발전이 끊임없 이 지속됨과 함께 사용자의 만족도가 매우 중요시 되고 있 다. 무선 환경에서 제한되고 불규칙적으로 변화하는 대역 폭을 어떻게 활용할 것인지에 따라 사용자의 만족도가 좌 우된다고 할 수 있다. 본 논문의 제안 방법은 주어진 대역폭 을 정확히 예측하고 최대한 사용할 수 있도록 하였기 때문 에 사용자의 만족도를 높이는데 도움을 줄 수 있다.

\section{참 고 문 헌}

[1] IEEE Standard for Local and metropolitan area networks Part 16: Air Interface for Broadband Wireless Access Systems, Oct. 2004.

[2] K. H. Teo, Z. Tao and J. Zhang, "The mobile broadband WiMAX standard," IEEE Signal Processing Mag., Vol. 24, pp.144-148, Sep.2007.

[3] J. Wang, M. Venkatachalam and Y. Fang, "System Architecture and Cross-Layer Optimization of Video Broadcast over WiMAX”, IEEE Journal on Selected Areas in Communications, Vol.25, pp.712-721, May.2007.

[4] P. Hosein, "Broadcasting VBR traffic in a WiMAX network," Vehicular Technology Conference, 2008. VTC 2008-Fall, IEEE 68th, pp.1-5, Sep.2008.

[5] H. Juan, H. Huang, H. Huang and T. Chiang, "Scalable Video Streaming over Mobile WiMAX," Circuits and Systems, 2007. ISCAS 2007. IEEE International Symposium on, pp.3463-3466, May.2007.

[6] S. H. Hong, Y. H. Lee, J. Y. Jung and D. Y. Suh, "A Cross-Layer Approach to Fair Resource Allocation for Multimedia Service in WiMAX”, KSII Transactions on Internet and Information Systems, Vol. 4, pp.1006-1022, Dec.2010.

[7] S. Sharangi, R. Krishnamurti and M. Hefeeda, "Energy-Efficient Multicasting of Scalable Video Streams OverWiMAX Networks," IEEE Transactions on Multimedia, pp.102-115, Feb.2011.

[8] H. S. Kim, H. M. Nam, J. Y. Jeong, S. H. Kim and S. J. Ko, "Measurement Based Channel-Adaptive Video Streaming for Mobile 
Device over Mobile WiMAX”, IEEE Transactions on Consumer Electronics, Vol. 54, pp.171-178, Feb.2008.

[9] H. S. Kim, E. S. Ryu and Jayant, N. "Channel-Adaptive Video
Transmission Using H.264 SVC Over Mobile WiMAX network", 2010 Digest of Technical Papers International Conference on Consumer Electronics, pp.441, Jan. 2010.

저 자 소 개

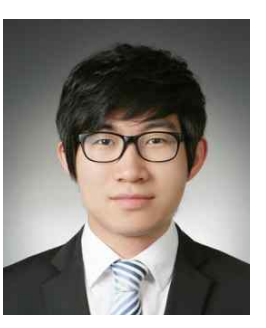

\section{김 민 건}

- 2009년 8월 : 경희대학교 전자전파공학과 (공학사)

- 2011년 8월 : 경희대학교 전자전하공학과 (공학석사)

- 주관심분야 : networed video, Cross Layer Optimization, DVC

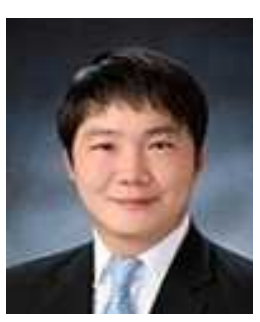

\section{김 준 오}

- 2010년 2월 : 경희대학교 전자전파공학과 (공학사)

- 2010년 3월 현재 : 경희대학교 전자전파공학과 (공학석사)

- 주관심분야 : networked video, MPEG, Cross Layer Optimization

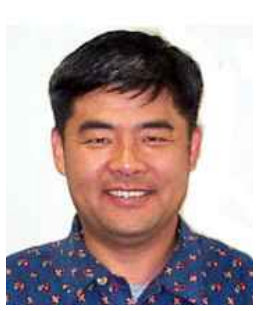

\section{서 덕 영}

- 1980년 2월 : 서울대학교 핵공학과 (공학사)

- 1986년 6월 : 미국 조지아텍 핵공학과 (공학석사)

- 1990년 6월 : 미국 조지아텍 전기·컴퓨터공학과 (공학박사)

- 1990년 9월 1999년 2월 : 생산기술연구원 HDTV 연구단 선임연구원

- 1992년 3월 현재 : 경희대학교 전자정보학부 교수

- 주관심분야 : networked video 